\title{
AGGRESSION AS A CRIME IN INTERNATIONAL AND NATIONAL CRIMINAL LAW
}

\begin{abstract}
The article analyzes the process of international criminalization of the crime of aggression, the role and significance of the Charter of the Nuremberg Tribunal for the formation of the modern concept of aggression, compares the definitions of aggression as a punishable offense committed by individuals, according to the Statute of the International Criminal Court, in line with the amendments made in 2010 by the Assembly of States that are Parties to the Court and the corpus delicti of the crime provided in Article 384 of the Criminal Code of the Republic of Armenia - "Aggressive War". The correlation developed by the author allows us to offer scientifically grounded recommendations on the qualification of the acts that constitute the crime of aggression, including the cases where it is accompanied by the commission of criminal violations of the laws and customs of conducting military operations.
\end{abstract}

Keywords: international crimes, international criminal law, international criminal court, qualification of aggression.

"History teaches that wars begin when governments believe the price of aggression is cheap."

Ronald Reagan

The goals and objectives of this article are to consider legal problems related to criminal law emerging in the prosecutorial and investigative practice of the criminal justice authorities of the Republic of Armenia when qualifying the act of aggression and ways to overcome them. In this article, we will express our view on the qualification of aggression. We are aware that the complexity and novelty of the raised legal issues inevitably imply the existence of different points of view and approaches for solving them, since the problems of qualifying aggression are associated with complex and multifaceted aspects.
Firstly, international humanitarian law establishes a direct dependence of the qualification of aggression and other war crimes on the nature of the armed conflict. Secondly, the characteristics of aggression as a crime are not identical in national and international criminal law.

Beginning in the middle of the $16^{\text {th }}$ century, professor at the University of Salamanca F. de Vitoria wrote that wars can only be fought to correct a wrong cause. Moreover, "if a subject is convinced of the injustice of a war, he may not serve in it, even though his sovereign commands" (Lukashuk \& Ledyakh, 1995, p. 116). 
Spanish scientist of the same era, B. Ayala, argued that "wars cannot be declared against Gentiles only because they are Gentiles, even by order of an emperor or the Pope". War can be used only in self-defense or as an extreme means for ensuring law, "when justice and reason have failed" (Lukashuk \& Ledyakh, 1995, p. 117).

Hugo Grotius, considered a fair, permitted war only the one that was launched in response to a violation of law. War is permissible as selfdefense: "In the event of an attack on people with open force and the impossibility of avoiding otherwise the danger to life, war is permitted, even entailing the killing of an attacker" (Grotius, 1956, pp. 186-188).

According to B. Ferenz (1983), many of Vitoria's ideas formulated in the first half of the $16^{\text {th }}$ century, such as elements of defining aggression, boundaries of acceptable self-defense, (...) responsibility of heads of States, groundless references to orders from a superior for their protection, were early predecessors of doctrines, which became recognized principles of international law four centuries later (p. 8).

Thus, despite the fact that the idea of the wrongfulness of an aggressive war emerged beginning in the middle of the $16^{\text {th }}$ century, the legal prohibition of aggression was established only in the $20^{\text {th }}$ century. So, in accordance with UN General Assembly Resolution No. 3314 adopted on 14 December, 1974, aggression is meant as a usage of armed force by one state against the other's sovereignty, territorial integrity and political independence, or in any other manner incompatible with the UN Charter ${ }^{1}$.

Article 3 of this Resolution provides a nonexhaustive list of acts the commission of which constitutes an act of aggression ${ }^{2}$. Analysis of the

Charter of the United Nations, 25 June 1945.

See Charter of the United Nations, 25 June 1945. concept of "aggression" allows us to conclude that the fact of the declaration of war itself does not make it legal, and the Resolution, which was often referred to, until recently, was not a binding document for States, and the definition of aggression as an international crime also was not worked out, moreover the Resolution describes the actions of States, and not individuals - subjects of the crime of aggression (Trikoz, 2011, pp. 20-23; Bogush, 2010, pp. 87-95). This approach is related to the fact that aggression is distinguished as an act of a State for which they can be brought to international legal responsibility, and aggression as a criminal offense committed by individuals for which they can be criminally liable (Marusin, 2013, pp. 112-120).

After Nuremberg and until the establishment of the International Criminal Court (hereinafter ICC), not a single international court was vested with jurisdiction related to the crime of aggression. After 1946, no international or national criminal court considered this crime, although in several cases the UN Security Council decided that the act of aggression was committed by states (Cassese, 2003, p. 112). As rightly noted by I. S. Marusin (2013), in the statutes of international criminal judicial institutions created later, such as the International Tribunal for the Former Yugoslavia, the International Tribunal for Rwanda, the Special Court for Sierra Leone, aggression was not included in the number of crimes covered by the jurisdiction of these bodies, which due to the fact that armed conflicts, during which the crimes pursued by these international judicial institutions were committed, were (mainly) of intra-State nature (pp. 112120).

Despite the fact that the original version of the Rome Statute of the ICC in Article 5 already provided for the jurisdiction over aggression, 
however, according to paragraph 2 of Article 5 of the Statute, it was regulated that the ICC shall exercise jurisdiction over the crime of aggression once a provision defining this crime and setting out the conditions of jurisdiction is adopted. Therefore, the participating States were not able to agree on an acceptable definition of this crime immediately. In 2002, on the basis of a Resolution of the Assembly of States - Parties to the Statute of the ICC, a Special Working Group on Aggression was established. ${ }^{3}$

From May 31 to June 11, 2010, at the $13^{\text {th }}$ meeting of the conference on international criminal justice in the Ugandan capital Kampala, a Conference was held, which was attended by 86 delegations of participating States and 33 observer states, on the review of the Rome Statute of the ICC.

The outcome of the ICC Conference of States Parties was the adoption on June 11, 2010, by consensus, of Resolution RC/Res.6 "Crime of Aggression", which provides for the inclusion in the Rome Statute of new articles 8 bis, 15 bis, 15 ter defining the crime of aggression and harmonizing the order of the ICC jurisdiction. So, in two paragraphs of the new article of the Statute of the ICC 8 bis, a unified substantive definition of the crime of aggression. ${ }^{4}$

3 See: RC/Res.6, R. (11 June 2010.). "The Crime of Aggression". Annex I. Amendments to the Rome Statute of the International Criminal Court on the Crime of Aggression.

4 "Article 8 bis

Crime of aggression

1. For the purpose of this Statute, "crime of aggression" means the planning, preparation, initiation or execution, by a person in a position effectively to exercise control over or to direct the political or military action of a State, of an act of aggression which, by its character, gravity and scale, constitutes a manifest violation of the Charter of the United Nations.

2. For the purpose of paragraph 1, "act of aggression" means the use of armed force by a State against the sovereignty, territorial integrity or political independence of another State, or in any
Article 8 bis, adopted in 2010, defines the elements of aggression as criminal offense as follows: planning, preparing, initiating or execution an act of aggression by a person who is able to effectively direct or control the political and military actions of the State. We share the fair opinion of I. S. Marusin that, from the point of view of ordinary law enforcement practice, the recognition of acts listed in Article 8 bis criminal and criminally punishable should mean that all persons involved in the commission of these acts, both the organizers and the direct perpetrators, should bear criminal responsibility. In other words, if State A commits an act of aggression

other manner inconsistent with the Charter of the United Nations. Any of the following acts, regardless of a declaration of war, shall, in accordance with United Nations General Assembly resolution 3314 (XXIX) of 14 December 1974, qualify as an act of aggression:

(a) The invasion or attack by the armed forces of a State of the territory of another State, or any military occupation, however temporary, resulting from such invasion or attack, or any annexation by the use of force of the territory of another State or part thereof;

(b) Bombardment by the armed forces of a State against the territory of another State or the use of any weapons by a State against the territory of another State;

(c) The blockade of the ports or coasts of a State by the armed forces of another State;

(d) An attack by the armed forces of a State on the land, sea or air forces, or marine and air fleets of another State;

(e) The use of armed forces of one State which are within the territory of another State with the agreement of the receiving State, in contravention of the conditions provided for in the agreement or any extension of their presence in such territory beyond the termination of the agreement;

(f) The action of a State in allowing its territory, which it has placed at the disposal of another State, to be used by that other State for perpetrating an act of aggression against a third State;

(g) The sending by or on behalf of a State of armed bands, groups, irregulars or mercenaries, which carry out acts of armed force against another State of such gravity as to amount to the acts listed above, or its substantial involvement therein." 
against neighboring State $\mathrm{B}$, then, according to this approach, both the head and the supreme commander of State A, who ordered the attack on State B, and all military personnel, including ordinaries, who fulfilled this order, should be held criminally responsible.

However, the adopted Article 8 bis indicates the circle of persons liable for aggression. These are, firstly, people who are able effectively to exercise control over the political or military actions of a State, and secondly, people who are able effectively to exercise the directing of political or military actions of a State. "Effectively" directing the actions of a State means that not all persons formally legally authorized to execute the act of aggression, such as the head of State, head of government or supreme commander, can be held accountable for an act of aggression, but only those who actually possessed such power (Marusin, 2013, pp. 112-120).

Such an approach, in our opinion, is caused not by a condescending attitude towards direct executors, but by exceeding the limits of the criminal law mechanism and the inability to prosecute thousands or a million representatives of the opposing side of an armed conflict without depriving them of their fundamental procedural rights and judicial guarantees. No judicial system can cope with so many accused, defendants and convicts. At the same time, the management of a State, in which such a number of accused, defendants and convicts will simultaneously appear, would be extremely difficult. But one can bring to justice one hundred, two hundred, a thousand people. It is precisely because of these considerations that the victorious states in the Second World War during the Nuremberg trials of 1945, the circle of persons responsible for the crimes committed by Germany was narrowed to the highest political and military leaders of the country. Millions of German and Austrian generals, officers, and soldiers who directly committed war crimes were not held accountable. The States participating in the ICC also did in the same manner. It is true that in the Statute of the Nuremberg Tribunal, the circle of persons liable for aggression was not precisely defined. All defendants at the Nuremberg Tribunal, according to the wording of Article 6 of the Charter, could be brought such accusation, but the circle of defendants at the Nuremberg Tribunal was individually determined (Marusin, 2013).

Thus, the first paragraph of Article 8 bis includes the main definition of a crime, the main constituent elements of which are: the first - elements of the "actus reus" (alternative nature of the types of active actions, a special "threshold of gravity" in the form of "gross violation" of the UN Charter, blank description of an act of aggression with reference to the "Definition of Aggression' of 1974), the second is a special subject that characterizes this crime as "leadership crime". The characteristics of the "mens rea" of a crime are disclosed in the "Elements of Crimes" of the ICC Statute 2002, which were also supplemented by relevant provisions: the offender must have been aware of factual circumstances that established that such a use of armed force was inconsistent with the Charter of the United Nations, also the circumstances indicating a gross violation of the UN Charter by its character, gravity and scale of the act of aggres-

\footnotetext{
5 I.e. persons who are able effectively to exercise control over the political or military actions of the state, and people who are able effectively to direct the political or military actions of the state. "Effectively" means that not all persons who formally have legal authority to carry out an act of aggression (head of State, head of government or supreme commander) can be held accountable for an act of aggression, but only those who actually possessed such power, even from among those persons who do not have such formal legal powers.
} 
sion.

Strictly speaking, the main elements of the crime of aggression in accordance with this definition are the following: the blanket nature of the objective side; a special subject that characterizes the crime as "leadership crime"; shold of gravity" in the form of a demand for a "gross violation" of the UN Charter. Even a single shelling of the territory of a foreign State according to the Definition of 1974 and Article 8 bis of the ICC Statute should be considered an act of aggression, but if the incident is quickly resolved, then there is obviously no need for the ICC to intervene. And in this case, the provisions of the ICC Statute provide for the responsibility for the outbreak and conduct of an aggressive war, and not for any single acts of the use of armed force. In addition, the two new Articles 15 bis and 15 ter of the Statute establish a different procedure for the exercise of the Court's jurisdiction over the crime of aggression. This is due to the role of the UN Security Council in establishing the fact that the State committed an act of aggression and with the restrictions on the territorial and personal jurisdiction of the Court. It should be noted that the competence to determine whether an event of international life is an aggression belongs only and exclusively to the UN Security Council (Article 39 of the UN Charter). However, such an assessment of the UN Security Council, in our opinion, is political, not legal.

So, when preparing the Statute of the ICC, some permanent members of the UN Security Council believed that as aggression can be considered only those actions that were qualified as

6 In the novel Article on the crime of aggression is included the reference to the "Definition of aggression" approved by the Resolution of the General Assembly of the UN number 3314 (XXIX) on 14 December 1974, and its text is reproduced (point $2 \mathrm{Ar}-$ ticle 8 bis of the Charter). such by the UN Security Council (Arsanjani, 1999, p. 29; Kolodkin, 1998, pp. 231-232). If such proposal were accepted, it would mean that the actions of any of the permanent members of the Security Council would never have been recognized as aggression, since the relevant state has the opportunity to veto a resolution in which its actions are qualified as such. However, this proposal was not accepted in the end. Thus, Article 15 bis of the ICC Statute is prescribed for the case when the situation is transferred to the ICC by a State party or when the prosecutor initiates an investigation by proprio motu and establishes the following procedure for initiating proceedings in the Court on charges of aggression. If the Prosecutor comes to the conclusion that there are sufficient grounds for initiating the criminal prosecution of a certain person on this charge, then he must first find out did the UN Security Council qualify as aggression the actions now being considered by the Prosecutor, and also notify the UN Secretary General of his intentions by providing him with all the necessary materials and documents. If such a qualification by the Security Council has already been implemented, as well as if the Security Council has not given any assessment of this situation and will not give it within 6 months after the Prosecutor has notified the UN Secretary General of his intention to initiate criminal prosecution, the Prosecutor has the right to continue the proceedings in this case under the usual manner. Thus, the UN Security Council can, qualifying certain actions not as aggression, thereby stopping the proceedings in this case at the ICC. But if the Security Council cannot qualify a particular situation, then the ICC will be able to act in accordance with its assessment. However, qualifying the actions of a particular State as aggression does not mean that the persons who directed these actions or exercised 
control over them are liable in the ICC. Article 15 ter of the Statute, in its turn, refers to the exercise of jurisdiction by the Court when transferring a situation by the UN Security Council. In this case, the jurisdiction of the ICC may be carried out in relation to any crimes, including those committed in the territory of the "third States" or by their citizens.

Moreover, a two-stage procedure for the entry into force of new jurisdictional provisions of the Statute is provided. Firstly, the jurisdiction of the Court is possible only after the amendments are confirmed by a majority vote of $2 / 3$ in the Assembly of States - Parties after January 1, 2017. Secondly, the Court can exercise jurisdiction over the crime of aggression only if it was committed after a year from ratification of amendments by 30 participating States. In accordance with Article 15 bis, also included in the Rome Statute by this Resolution, the Court may exercise jurisdiction only with respect to crimes of aggression committed one year after the ratification or adoption of these amendments by thirty participating States.

The correlation of the definition "Crime of aggression" developed for the purposes of the ICC Statute has some specificity than Article 384 of the Criminal Code of the Republic of Armenia $^{7}$. The problem is that aggression as a crime under national and international criminal law is not identical. So, analysis and comparison of the Article 384 of the Criminal Code of the Republic of Armenia "Aggressive War", which is disclosed in two parts and contains two separate elements of a crime, provides for responsibility in part 1 for planning or preparing an aggressive war, and in part 2 for unleashing or waging an aggressive war. At the same time, the planning

The Criminal Code of the Republic of Armenia adopted on April 29, 2003, further the RA Criminal Code. of an aggressive war is understood as the fulfillment of any actions of an intellectual nature to achieve the goals of such a war, in particular: the development of its ideological, political and military concept; drawing up plans for strategies and tactics of military operations; mobilization plans; development of plans for the structure, composition, deployment and tasks of the armed forces; organization of intelligence activities; informational activity (Borzenkova \& Komissarova, 2002, pp. 354-355). The preparation of an aggressive war is understood as the implementation of actions aimed at implementing the developed plans of aggression: building up armed forces, accumulating weapons and ammunition, creating food supplies, intensifying intelligence against another State, conducting command-and-staff exercises to develop aggression, etc. (Kruglikov, 1999, p. 769). The outbreak of an aggressive war is the beginning of concrete actions for its conduct, with a view to its further conduct, and not an act of sporadic aggressive use of military force against another State. So, in the fair opinion of N. F. Kuznetsova, untying aggressive war is the facts of aggression, "preceding the fullscale conduct of an aggressive war" (Malakhov, 2003, p. 139), such as: diplomatic demarches with aggressive goals, reconnaissance, the seizure of ships and the like "acts of aggressive behavior" (Borzenkova \& Komissarova, 2002, pp. 357-358). Usually in the literature it is argued that the unleashing of aggression is a "treacherous" act committed in spite of the existence of peace treaties. The conduct of an aggressive war is a continuation of an aggressive war after the fact of its unleashing (Naumov, 2007, p. 610), and can be expressed in large-scale aggression against another state in the form of an attack, attack, invasion of its territory with the aim of capture or other aggressive purposes. It seems that 
the conduct of an aggressive war may be an undeclared conduct of hostilities against another state de facto - after all, legally, an act of aggression is stated regardless of the declaration of a state of war.

Thus, if the Article 384 of the RA Criminal Code establishes criminal liability in accordance with Article 3 "Definition of aggression," provided for by UN General Assembly Resolution No. 3314 of 14 December, 1974, even for a single shelling of a foreign state's territory, regardless of purpose and intent ${ }^{8}$, without specifying the subject, which from the point of view of ordinary law enforcement practice means that criminal liability for them should be borne by all persons who participated in the commission of these acts, both the organizers and the direct executors, then Article 8 bis establishes criminal liability for an act of aggression, which by its character, seriousness or scale is a gross violation of the UN Charter, and not for any single acts of the use of armed force, narrows the range of persons who hold criminal responsibility for aggression only by the highest state and military leaders, freeing from it lower-level performers, i.e., generals, officers and ordinary, directly and carrying out actions that qualify as aggression ${ }^{9}$. Such a restriction testifies to the desire of the ICC Member States to consider really significant, serious crimes, and if a single shelling of the territory of a foreign state, which should be considered an act of aggression, is quickly settled, then there is no need for ICC intervention.

8 In the point 1 of Article 5 of "Definition of Aggression" of 1974 is clearly stated that "No consideration of whatever nature, whether political, economic, military or otherwise, may serve as a justification for aggression".

9 By this aggression differs from other types of international crimes, for example, from genocide, for the commission of which to criminal liability are brought all people who participated in its commission - both the directors and the executors.
On this occasion, we share the fair opinion of I. S. Marusin (2013, p. 119), who notes that such a position of the States - Parties to the ICC of the court could be agreed if the text of the Statute or the Rules of Procedure and Evidence would give objective criteria for distinguishing an manifest (gross) violation of the UN Charter. That means the criteria for this assessment in the normative acts, on the basis of which the ICC should make its decisions, are absent. The Appendix to the "Elements of Crimes", adopted simultaneously with the amendments to the Statute of the ICC, only states that the term "manifest" is an objective characteristic (Article 8 bis, paragraph 3 of the Introduction). This means that a person's subjective assessment of his actions as legitimate or as violating the provisions of the UN Charter, but not rudely, does not relieve him of responsibility. At the same time, the grounds for holding accountable for aggression are formulated in the adopted amendments to the ICC Statute so that they allow for a different approach to similar situations and leave too much room for judicial discretion. This situation necessitates the introduction of appropriate amendments and expansion of the circle of persons responsible for the crime of aggression.

In the framework of the goals and objectives of this article, it is also necessary to consider such an important question: how to qualify the conduct of an aggressive war if such actions are accompanied by the commission of criminal violations of the laws and customs of military operations.

It seems that the commission of war crimes in the course of an aggressive war should always receive an independent legal assessment - that is, the deed should be qualified in the totality of crimes.

International humanitarian law establishes a 
direct dependence of the qualifications of aggression and other war crimes on the nature of the armed conflict, recognizing similar acts, in some cases, as military and other international crimes, but not in others. To date, individual criminal liability for war crimes committed during conflicts of a non-international nature is a norm of customary international law, which is also confirmed by the practice of international organizations. So Article 7 of the Resolution of the UN General Assembly No. 3314 of 14 December, 1974, provides for the provision that nothing in this definition, and in particular in Article 3, can in any way prejudice the right of peoples to selfdetermination, freedom and independence arising from the Charter, as well as the right of these peoples to fight this purpose ${ }^{10}$. However, the interpretation and application of the above provisions should be interrelated and each provision should be considered in the context of all other provisions. Such an approach, in our opinion, is legally legitimate. However, qualifying the actions of a certain state as aggression does not mean that the persons who directed these actions or exercised control over them are liable in the ICC.

It seems that if the outbreak and the conduct of an aggressive war are accompanied by the commission of other war crimes, the latter must always be qualified independently, i.e., accord-

10 According to the Article 7 of the Resolution of the UN General Assembly number 3314 of 14 December 1974, "Nothing in this Definition, and in particular article 3 , could in any way prejudice the right to selfdetermination, freedom and independence, as derived from the Charter, of peoples forcibly deprived of that right and referred to in the Declaration on Principles of International Law concerning Friendly Relations and Cooperation among States in accordance with the Charter of the United Nations, particularly peoples under colonial and racist regimes or other forms of alien domination: nor the right of these peoples to struggle to that end and to seek and receive support, in accordance with the principles of the Charter and in conformity with the above-mentioned Declaration". ing to the totality of crimes provided for in part 2 of Article 384 of the Criminal Code of the Republic of Armenia "Aggressive war" and part 1 of Article 387 of the RA Criminal Code "The use of means and methods of war prohibited by an international treaty in military operations or armed conflicts", and in some cases in conjunction with Article 390 of the Criminal Code of the Republic of Armenia "gross violations of international humanitarian law during armed conflicts".

Thus, the question of the possible prosecution of the crime of aggression is currently devoid of any practical plane and remains the subject of academic theorizing. This statement also applies to the ICC until the ICC considers such crimes in its practice. In any case, prosecution of representatives of the opposing side of an armed conflict for committing a crime of aggression is currently possible only at the international level. Nevertheless, in our opinion, such a qualification of the offense under national law is most correct due to its obviousness and legal certainty.

\section{REFERENCES}

Arsanjani, M. (1999). The Rome Statute of the ICC. Americal Journal of International Law, $N$ 1, 22-43.

Bogush, G. (2010). Obzornaya konferencia po Rimskomu statutu: novie gorizonti mezhdunarodnovo ugolovnovo pravosudiya (Overview Conference on Roman Statute: New Prospects of International Criminal Justice, in Russian). Sravnitelnoye konstitucionnoye obozreniye (Competitive Constitutional Overview), 5, 87-95.

Borzenkova, V. S., \& Komissarova, G. (Eds.). (2002). Kurs ugolovnovo prava. Oso- 
bennaya chast' (Course of Criminal Law. Special Part, in Russian). (Vol. 5). Moscow: Zercalo.

Cassese, A. (2003). International Criminal Law. Oxford: OUP Higher Education Division.

Ferenz, B. (1983). Enforcing International Law - A Way to World Peace. (Vol. 1). London-New York: Oceana Publications Inc.

Grotius, G. (1956). O prave voiny i mira (The Laws of War and Peace, in Russian). Moscow: Ladomir.

Lukashuk, I. I. \& Ledyakh, I. (Eds.). (1995). Nyurenbergskii process protiv voiny $i$ fashizma (Nuremberg Process: the Law against War and Fascism, in Russian). Moscow: Volters Kluver.

Kolodkin, R. (1998). O mezhdunardnom ugolovnom sude (On International Criminal Court, in Russian). Russian Year Book of International Law, 1996-1997, 231232.

Kruglikov, L. (Ed.). (1999). Ugolovnoye pravo Rossii. Osobennaya chast (Criminal Law in Russia. Special Part, in Rus- sian). Moscow: BEK.

Malakhov, O. (2003). Agressia kak prestupleniye po nacional'nomu i mezhdunarodnomu pravu (Aggression as a Crime in National and International Law, in Russian). ( $\mathrm{PhD}$ dissertation). Stavropol.

Marusin, I. (2013). Opredelenie agresii v statute mezhdunarodnogo ugolovnogo suda $i$ ustave Nurenbergskovo tribunala (The Definition of Agression in the Statute of International Criminal Court and the Charter of the Nuremberg Tribunal, in Russian). Jurisprudence (Actual Issues Public Law and International Law), 4(309), 112-120.

Naumov, A. (2007). Rossiiskoe ugolovnoe pravo: kurs lekcii (Russian Criminal Law: the Course of Lectures, in Russian). Moscow: Volters Kluver.

Trikoz, E. (2011). Mezhdunarodnoye ugolovnoye pravo i mezhdunarodnaya yusticiya International Criminal Law and International Justice, in Russian). In Kampala International Conference on International Criminal Justice (Vol. 1, pp. 87-95). The Hague. Ipskamp. 